\title{
Rekontruksi Set Alat Praktikum Geolistrik pada Matakuliah Eksplorasi Geofisika di Departemen Pendidikan Fisika Universitas Pendidikan Indonesia
}

\author{
Cahyo Puji Asmoro ${ }^{{ }^{*}}$, Hana Susanti ${ }^{1}$, Nanang Dwi Ardi ${ }^{1}$ \\ ${ }^{1}$ Program Studi Fisika, Universitas Pendidikan Indonesia, Jl. Dr. Setiabudhi 229 \\ Bandung 40154, Indonesia
}

*Penulis Penanggungjawab.E-mail: cp.asmoro@upi.edu (Cahyo Puji Asmoro)

\begin{abstract}
ABSTRAK
Praktikum Metode Geolistrik bertujuan untuk menyelidiki keadaan bawah permukaan dengan menggunakan sifat-sifat kelistrikan batuan. Metode tersebut dengan menginjeksikan arus listrik ke dalam bumi melalui dua buah elektoda arus. Beda potensial yang terjadi diukur melalui dua buah elektroda potensial, dari hasil pengukuran arus dan beda potensial untuk setiap jarak elektroda tertentu, dapat ditentukan variasi harga tahanan jenis masing-masing lapisan di bawah titik ukur. Praktikum Metode Geolistrik merupakan salah satu pembelajaran pada mata kuliah Ekspolarasi Geofisika di Departemen Pendidikan Fisika, dari hasil pengamatan dan diskusi dengan praktikan di ketahui bahwa bentuk elektroda menjadi salah satu faktor penghambat dalam pengambilan data sehingga praktikum berjalan kurang efektif dan efisien. Penelitian ini dilakukan untuk mengetahui konstruksi ideal set alat geolistrik pada bagian elektroda, agar memperoleh data yang akurat terkait nilai tahanan jenis masing-masing lapisan bawah tanah dan mudah serta aman dalam penggunaannya. Metode penelitian yang digunakan adalah pengumpulan data berdasarkan eksperimen, untuk menganalisis elektroda secara desain akan dilakukan dari segi penggunaan dan berat dari elektroda sedangkan fungsi akan dilakukan metode geolistrik konfigurasi Schlumberger dengan menggunakan elektroda lama dan elektroda baru pada 2 lokasi dengan jenis lahan yang berbeda. Pengolahan data menunjukkan konstruksi Elektroda Baru memiliki kemampuan untuk pengambilan data yang lebih efektif dan efisien secara desain maupun fungsi sehingga bisa digunakan untuk Praktikum Metode Geolistrik.
\end{abstract}

Kata Kunci : Geolistrik; Elektroda; Resistivitas 


\begin{abstract}
The Geoelectric Method practicum aims to investigate subsurface conditions using the electrical properties of rocks. The method is by injecting an electric current into the earth through two current electrodes. The potential difference that occurs is measured through two potential electrodes, from the measurement of the current and potential difference for each particular electrode distance, the variation in the resistivity value of each layer below the measuring point can be determined. The Geoelectric Method Practicum is one of the lessons in the Geophysical Exploration course in the Department of Physics Education, from the results of observations and discussions with practitioners it is known that the shape of the electrode is one of the inhibiting factors in data collection so that the practicum runs less effectively and efficiently. This research was conducted to determine the ideal construction of the geoelectric device set at the electrode, in order to obtain accurate data regarding the resistivity value of each subsoil and it is easy and safe to use. The research method used is data collection based on experiments, to analyze the electrodes by design will be carried out in terms of use and weight of the electrodes while the function will be carried out by the Schlumberger configuration geoelectric method using the old electrode and the new electrode at 2 locations with different types of land. Data processing shows that the New Electrode construction has the ability to collect data more effectively and efficiently in terms of design and function so that it can be used for the Geoelectric Method Practicum.
\end{abstract}

Keywords: Geoelectric; Electrode; Resistivity

\section{Pendahuluan}

Praktikum metode geolistrik merupakan salah satu pembelajaran yang diperoleh pada mata kuliah Eksplorasi Geofisika dengan kode FI564 bagi para mahasiswa fisika di departemen Pendidikan fisika FPMIPA Universitas Pendidikan Indonesia yang mengambil bidang kajian fisika bumi. Capaian pembelajaran matakuliah ini adalah mahasiswa dapat 1. Memiliki kemandirian dalam memasang dan mengoperasikan alat geolistrik,
2. menjelaskan prinsip, akuisisi, pengolahan data dan pemodelan metode geolistrik, 3. Menerapkan teknologi alat geolistrik, 4. Memanfaatkan teknologi alat geolistrik, dan 5. Membuat solusi terhadap masalah lingkungan dengan menggunakan metode geolsitrik.

Metode geolistrik resistivitas bertujuan untuk menyelidiki keadaan bawah permukaan dengan menggunakan sifat-sifat kelistrikan (tahanan jenis) batuan. Prinsip kerjanya adalah arus listrik diinjeksikan ke dalam bumi melalui 
2 buah elektoda arus. Beda potensial yang terjadi diukur melalui 2 buah elektroda potensial, dari hasil pengukuran arus dan beda potensial untuk setiap jarak elektroda tertentu, dapat ditentukan variasi harga tahanan jenis masing-masing lapisan di bawah titik ukur. Metode geolistrik resistivitas digunakan untuk eksplorasi yang sifatnya dangkal seperti penentuan zonasi pencemaran air [1,2], identifikasi zona longsor [3,4], intrusi air garam [5], dan infiltrasi curah hujan ke permukaan tanah [6].

Berdasarkan tujuan penyelidikannya metode resistivitas dapat dibagi menjadi dua kelompok besar, yaitu sounding dan mapping. Sounding bertujuan untuk mengetahui variasi resistivitas lapisan bawah permukaan secara vertikal, dengan cara mengubah variasi jarak antar elektroda arus dan potensial, pada titik pengukuran yang sama. Mapping bertujuan untuk mengetahui variasi resistivitas lapisan bawah permukaan secara horisontal, dengan cara berpindah titik pengukuran tetapi mempertahankan jarak antar elektroda arus dan potensial [7]. Dari tujuan tersebut dapat kita ketahui bahwa konfigurasi elektroda menjadi kunci utama dalam metode survei geolistrik, ada 3 konfigurasi yang umum di gunakan yaitu konfigurasi Wenner, konfigurasi Schlumberger, dan konfigursi DipoleDipole.

Konfigurasi Wenner dilakukan dengan cara meletakkan titik titik elektroda dengan beda jarak satu sama lain yang sama, elektroda yang bersebelahan akan berjarak sama $(\mathrm{C} 1 \mathrm{P} 1=\mathrm{P} 1 \mathrm{P} 2=\mathrm{P} 2 \mathrm{C} 2=\mathrm{a})$. Konfigurasi Schlumberger dilakukan dengan cara yang sama dengan Wenner, namun jarak elektroda arus dapat diubah tidak sama dengan jarak elektroda potensial. Konfigurasi Dipole-dipole berbeda dengan dua konfigurasi sebelumnya, elektroda potensial diletakkan berjauhan dengan jarak n $a$ dari elektrode arus. Konfigurasi ini sangat baik untuk pemetaan secara horizontal atau lateral, jarak elektroda yang dibuat sama menghasilkan aliran arus listrik yang maksimal pada kedalaman tertentu sehingga kontras resitivitas horizontal dapat diperkirakan [8].

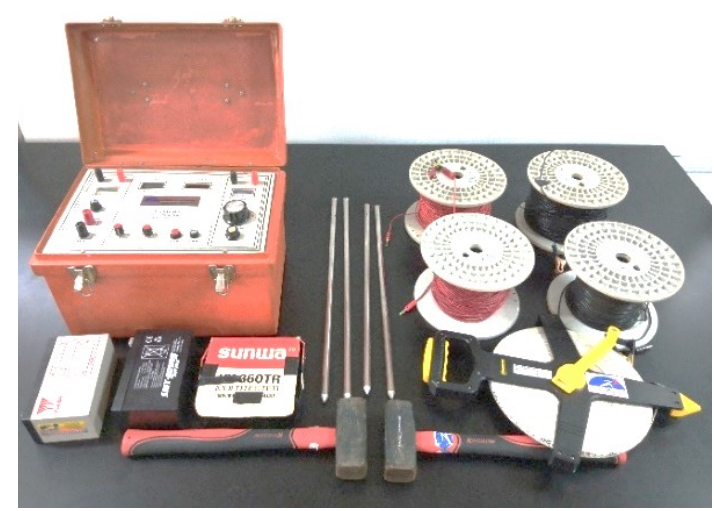

Gambar 1. Set Alat Praktikum Metode

Geolistrik

Alat Metode Geolistrik Resistivity Meter yang dimiliki oleh Departemen Pendidikan Fisika yang dalam hal ini dikelola oleh Laboratorium Bumi dan Antariksa adalah Naniura Model NRD 22 S (Gambar 1), temuan di lapangan 
berdasarkan pengamatan dan keluhan dari mahasiswa diketahui bahwa ketika proses penancapan elektroda pada bidang lintasan yang akan diukur memerlukan ekstra tenaga karena harus dipukul menggunakan palu dan kemudian dicabut. Langkah tersebut diulang kembali di titik lain dengan jumlah minimal titik penancapan 50 titik untuk satu lintasan pengukuran saja, sehingga untuk pengambilan data dalam sehari hanya bisa satu lintasan saja.

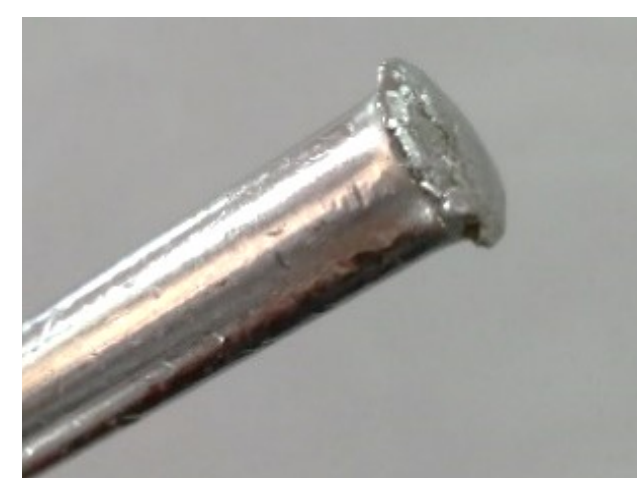

Gambar 2. Elektroda Lama

Proses pemukulan menggunakan palu juga menyebabkan elektroda menjadi terkikis dan pipihan tajam terlihat seperti pada gambar 2, selain itu risiko kecelakaan salah pukul atau tergores pipihan elektroda ketika proses pencabutan juga menjadi ancaman yang membahayakan aspek K3. Selain itu ketika proses membawa set alat geolistrik ini elektroda dan palu menjadi pemberi kontribusi signifikan terhadap total massa keselurahan set alat. Jumlah 2 buah palu menjadi dua sisi mata pisau, jika ditambah akan menambah beban bawaan dan jika tidak ditambah akan memakan waktu karena bergantian menggunakan palu untuk menancapkan elektroda apalagi untuk spasi elektroda yang panjang.

Tabel 1. Sebaran Masa Set Geolistrik

\begin{tabular}{cccc}
\hline No & Nama & Jumlah & Masa \\
\hline 1 & Resistivitimeter & 1 & $4,3 \mathrm{Kg}$ \\
\hline 2 & Multimeter & 1 & $0,6 \mathrm{Kg}$ \\
\hline 3 & Meteran & 1 & $1,2 \mathrm{Kg}$ \\
\hline 4 & Aki Kering & 2 & $4,2 \mathrm{Kg}$ \\
\hline 5 & Rol Kabel & 4 & $6 \mathrm{Kg}$ \\
\hline 6 & Elektroda & 4 & $\sim 2 \mathrm{Kg}$ \\
\hline 7 & Palu & 2 & $\sim 4 \mathrm{Kg}$ \\
\hline & Total & $\mathbf{1 5}$ & $\mathbf{2 3 ~ K g}$ \\
\hline
\end{tabular}

Peralatan praktikum di laboratorium menjadi hal penting dalam pencapaian target pembelajaran yang diinginkan [9]. Pemilihan alat dan bahan serta teknik yang tepat akan menjadi konstruksi dasar dalam mendapatkan data yang presisi sekaligus keamanan, baik untuk praktikum maupun penelitian. Berdasarkan masalah tersebut maka diperlukan rekonstruksi yang tepat untuk set alat geolistrik, dalam hal ini membuat elektroda dengan desain baru yang lebih efektif dan efisien, penelitian dilakukan ini untuk mengetahui fungsi dan kinerja dari elektroda baru.

\section{Bahan dan Metode}

Bahan yang digunakan dalam penelitian ini adalah 4 Gulung Kabel, 8 Jack Banana dan 2 buah Aki 12Volt. Adapun 
peralatan yang digunakan yaitu resistivitimeter Naniura NRD22S, multimeter, pengisi daya aki, 2 buah palu dan 4 buah elektroda lama dan 4 buah elektroda baru.

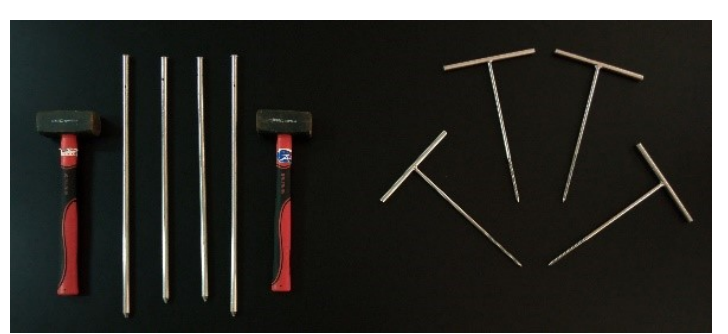

Gambar 3. Elektroda Lama dan Baru

Metode penelitian yang digunakan adalah metode eksperimen, elektroda baru yang telah berhasil dirancang, selanjutnya diuji dengan melakukan pengukuran dengan skala lapangan terbatas. Pada pengujian ini dilakukan pada 2 jenis tanah, kebun dengan panjang lintasan 20 meter menggunakan konfigurasi Schlumberger akan dilakukan analisis desain elektroda dan analisis fungsi.

Susunan elektroda konfigurasi Schlumberger [10] dapat dilihat pada Gambar 4. Adapun untuk persamaan resitivitas semu dijabarkan pada persamaan (1) sampai dengan (5) [11].

Beda potensial listrik antara elektroda $\mathrm{M}$ dan $\mathrm{N}$ adalah sebesar

$$
\Delta V=\rho \frac{I}{2 \pi}\left\{\left(\frac{1}{r_{A M}}-\frac{1}{r_{B M}}\right) \mid\left(\frac{1}{r_{A N}}-\frac{1}{r_{B N}}\right)\right\}
$$

Maka persamaan resistivitas menjadi

$$
\rho=2 \pi \frac{\Delta V}{l}\left\{\left(\frac{1}{r_{A M}}-\frac{1}{r_{B M}}\right) \mid\left(\frac{1}{r_{A N}}-\frac{1}{r_{B N}}\right)\right\}^{-1}
$$
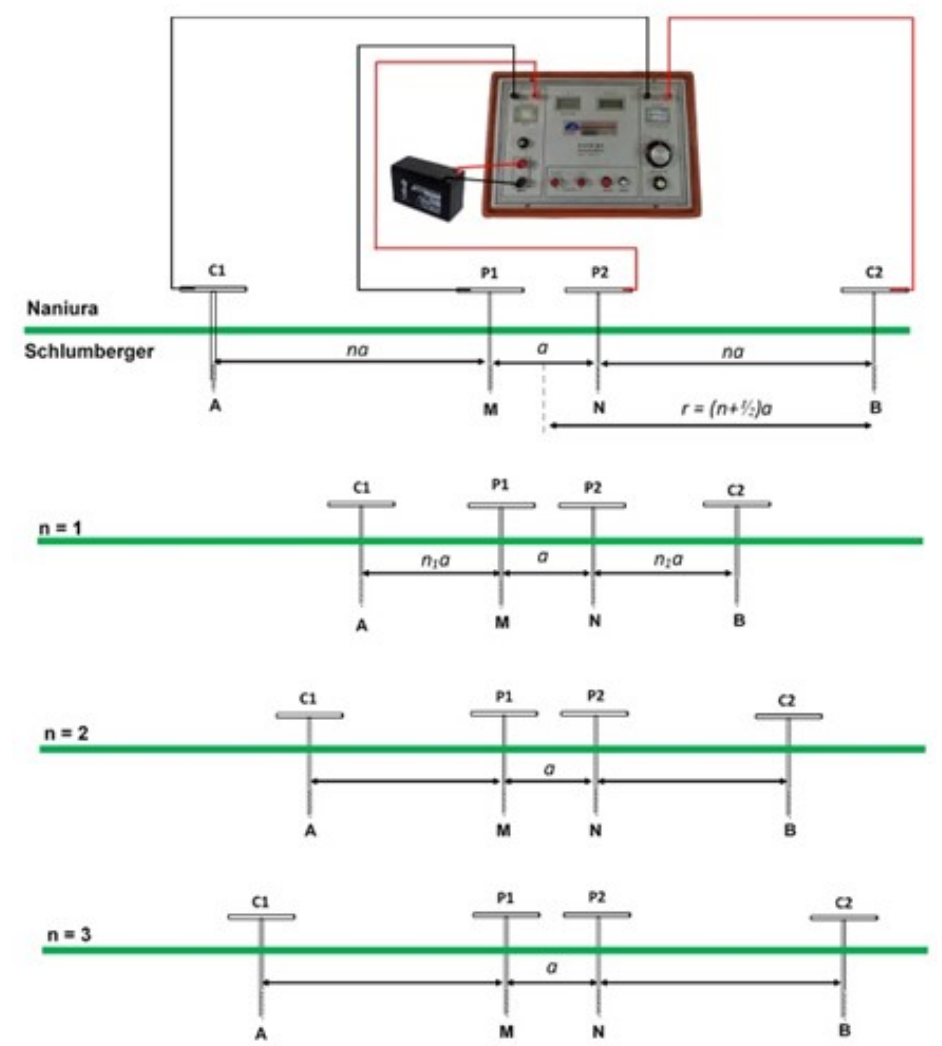

Gambar 4. Metoda Geolistrik Konfigurasi Schlumberger 


$$
\rho=n(n+1) a \pi \frac{\Delta V}{I}
$$

dimana $k$

$$
k=n(n+1) a
$$

Maka

$$
\rho=k \pi \frac{\Delta V}{I}
$$

Dengan $\rho$ adalah resitivitas semu ( $\Omega . \mathrm{m})$, $k$ adalah faktor geometri konfigurasi, $\Delta V$ adalah beda potensial (Volt) dan $I$ adalah besar kuat arus (ampere).

Data yang diperoleh dari hasil pengukuran adalah data beda potensial dan kuat arus, kemudian dihitung nilai resitivitas pada persamaan (5) dan dilanjutkan dengan pengolahan menggunakan software Progress $[12,13,14]$. Berdasarkan hasil pengolahan data tersebut diperoleh penampang geolistrik resitivitas vertikal terhadap kedalaman.

Kemudian dibandingkan data yang dihasilkan oleh elektroda baru dan elektroda lama apakah memiliki kemampuan yang sama atau lebih baik dalam menghasilkan data yang akan kita tinjau dari error data yang diperoleh.

\section{Hasil dan Pembahasan}

\subsection{Analisis Desain Elektroda}

Elektroda baru yang telah dibuat secara desain memiliki tingkat efektif lebih baik karena dalam penggunaannya dikarenakan tidak memerlukan palu untuk ditancapkan ke tanah (Gambar 5), resiko K3 akan lebih aman.

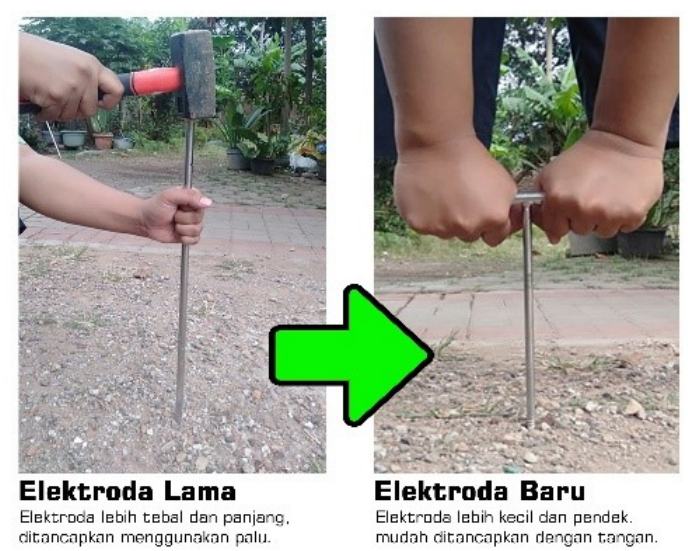

Gambar 5. Cara penancapan elektroda

Dari segi waktu pengukuran satu kegiatan pengambilan data dengan 18 titik pengukuran untuk masing-masing elektroda pada 2 jenis lahan tanah dapat dilihat pada tabel 2, waktu pengukuran di tanah urug lebih lama karena kondisi tanah yang cukup keras, penggunaan elektroda baru lebih cepat 8 menit dibandingkan penggunaan elektroda lama. Sedangkan pada tanah kebun yang kondisi tanah lebih lunak waktu pengukuran lebih cepat untuk semua tipe elektroda, selisih waktu selama 4 menit lebih cepat untuk pengunaan elektroda baru.

Tabel 2. Waktu Pengukuran Geolistrik

\begin{tabular}{ccc}
\hline No & Pengukuran & Waktu \\
\hline 1 & Tanah Urug Eletroda & 50 Menit \\
Baru & 58 Menit \\
2 & $\begin{array}{c}\text { Tanah Urug Eletroda } \\
\text { Lama }\end{array}$ & 31 Menit \\
3 & $\begin{array}{c}\text { Tanah Kebun Eletroda } \\
\text { Baru }\end{array}$ & 35 menit \\
4 & $\begin{array}{c}\text { Tanah Kebun Eletroda } \\
\text { Lama }\end{array}$ \\
\hline
\end{tabular}


Bentuk elektroda yang lebih kecil dan pendek memberikan konsekuensi terhadap massa elektroda, di mana elektroda lama memiliki massa 483gram dan untuk elektroda lama memiliki masa 273 gram (Gambar 6). Dengan selisih 210 gram/elektroda, maka untuk 4 elektroda akan mengurangi massa beban untuk mobilisasi Set Alat Praktikum sebesar 0,84 kg dan 4 $\mathrm{kg}$ dari 2 palu yang tidak digunakan.

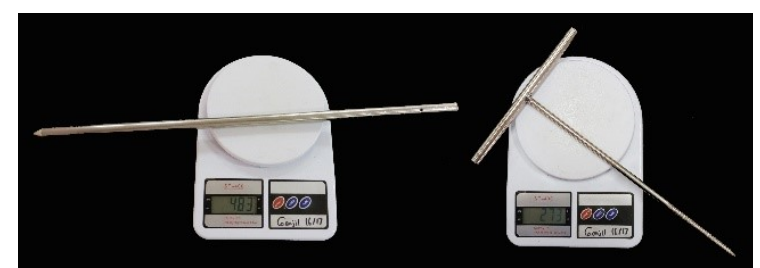

Gambar 6. Perbandingan massa elektroda

\subsection{Analisis Fungsi Elektroda}

Lokasi penelitian berada di wilayah Kelurahan Baros, Kota Cimahi, Jawa Barat dengan kondisi tanah yang berbeda untuk menguji kemampun elektroda baru, yaitu lokasi (A) Tanah Urug dan (B) Tanah Kebun (Gambar 7) dengan masing-masing lintasan sepanjang 20 meter dengan konfigurasi Schlumberger. Di mana jarak antar elektroda potensial (a) dibuat tetap sepanjang 0,5 meter dan $\mathrm{n}_{1}=2 \mathrm{a}$ atau 1 meter, dan $\mathrm{n}_{2}, \mathrm{n}_{3}, \mathrm{n}_{4}$ dan seterusnya bertambah 0,5 meter.

\section{(A) Lokasi Tanah Urug}

Pada Gambar 8 dan Gambar 9 dapat terlihat bahwa pola grafik yang terbentuk hampir sama persis, baik dalam pengukuran dengan pengunaan elektroda baru maupun lama, mengacu pada nilai resistivitas tiap spasi pun memiliki nilai yang tidak terlalu jauh sebagai contoh pada spasi 1,5 meter di dapatkan nilai resistivitas tanah

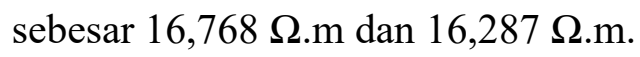

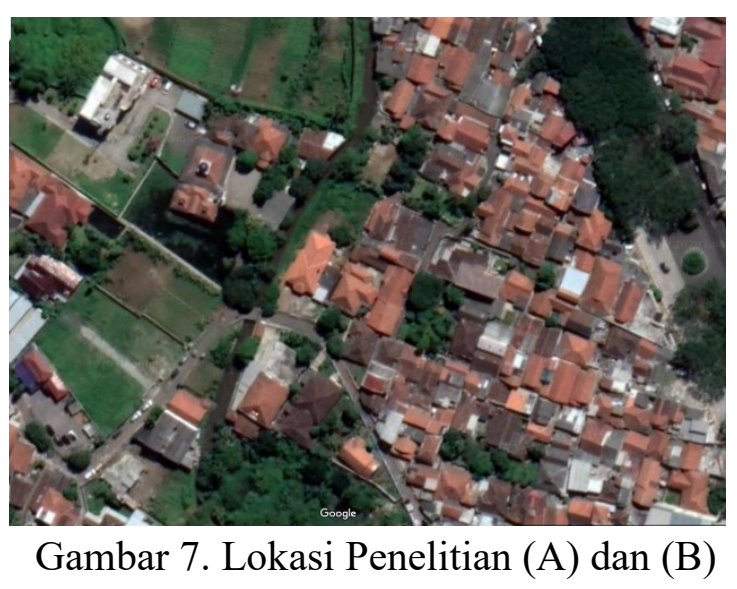

Pengolahan menggunakan software Progress, didapatkan 7 penampang/lapisan di lokasi tanah urug. Gambar 8 dan 9 pada bagian Resitivity Log memperlihatkan kesamaan nilai resistivitas lapisan tanah yaitu pada lapisan pertama di kedalaman 0 0,7 meter memiliki nilai resistivitas \pm 19 $\Omega . m$, lapisan ke dua di kedalaman $0,7-0,9$ meter memiliki nilai resistivitas $\pm 2,7 \Omega . \mathrm{m}$ dan lapisan ke tiga di kedalaman 0,9 - 1,2 meter memiliki nilai resistivitas pada rentang

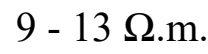

Dengan Panjang lintasan 20 meter dengan spasi 0,5 meter dan faktor $\mathrm{n}=10$ maka berdasarkan data tabel Loke maka perkiraan kedalam yang didapat adalah $20 \times 0.191=$ 3,82 meter [14]. Jika melihat data yang tersaji maka pada kedalaman $0-3,82$ meter masih memiliki resistivitas yang hampir 


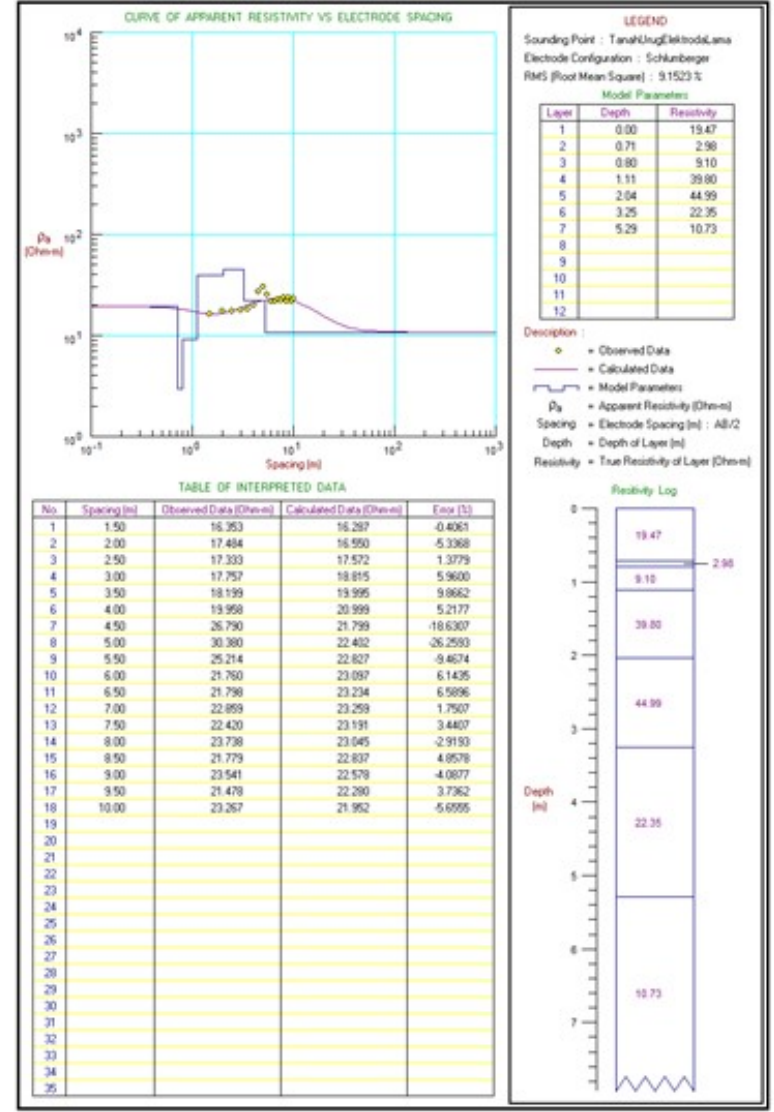

Gambar 8. Hasil Software Progress pada tanah urug dengan elektroda baru

sama, dan lebih dalam lagi memiliki resistivitas yang bervariasi maksimal di 62 Л.m. Berdasarkan nilai tersebut dapat diinterprestasikan bahwa lapisannya masih sama yaitu tanah lempung dan sedikit ada pasiran yang mungkin dari hasil urugan berupa batuan.

Mengacu pada RMS (Root Mean Square) atau error data diperoleh untuk profil data dengan elektroda baru 8,32\% dan profil data dengan elektroda lama 9,15\%. Hanya selisih $0,8 \%$ dan masih di bawah $10 \%$ sebagai batas bawah error suatu data [15].

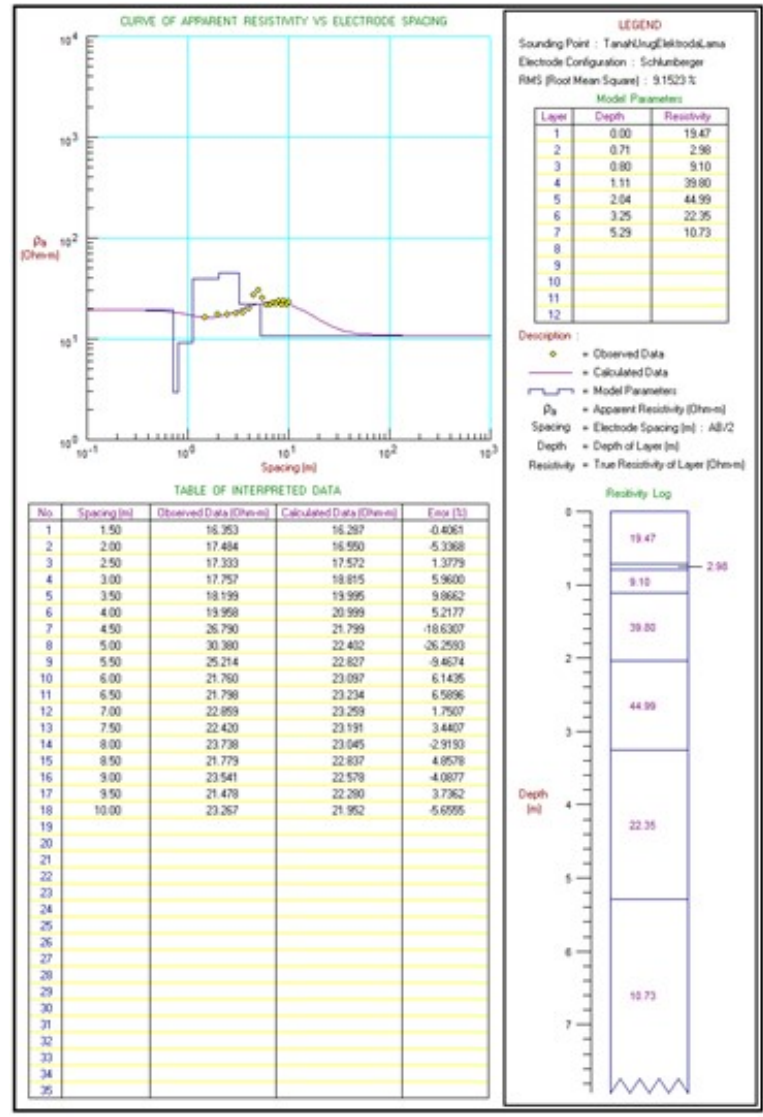

Gambar 9. Hasil Software Progress pada tanah urug dengan elektroda lama

\section{Lokasi Tanah Kebun}

Dari Gambar 10 dan Gambar 11 juga terlihat bahwa pola grafik yang terbentuk hampir sama baik pada pengukuran dengan penggunaan elektroda baru maupun lama, mengacu pada nilai resistivitas tiap spasi pun memiliki nilai yang tidak terlalu jauh sebagai contoh pada spasi 3 meter di dapatkan nilai resistivitas tanah sebesar 23,442 $\Omega . m$ dan

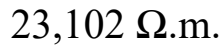

Pengolahan menggunakan software Progress, pada tanah kebun pun kita mendapatkan 7 penampang/lapisan. Pada Gambar 10 dan 11 di bagian 


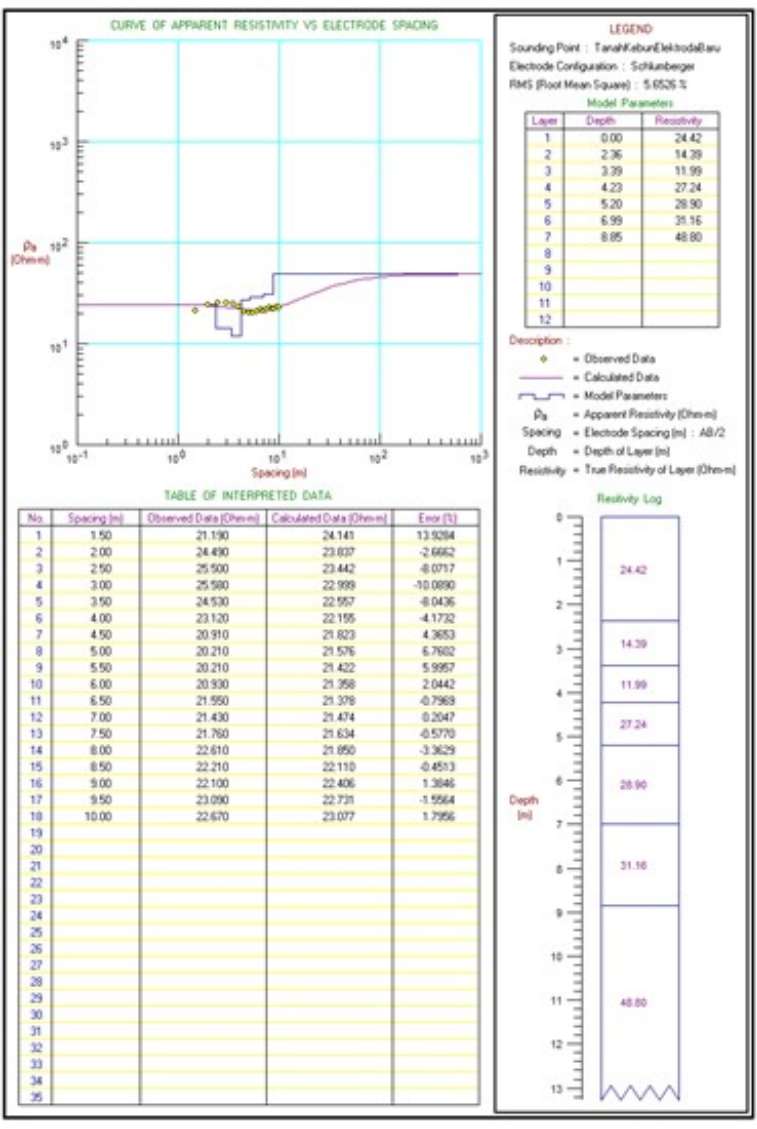

Gambar 10. Hasil Software Progress pada tanah kebun dengan elektroda baru

Resitivity Log menunjukkan kesamaan nilai resistivitas lapisan tanah yaitu pada lapisan pertama di kedalaman $0-2,1$ meter memiliki nilai resistivitas $\pm 24,4 \Omega . \mathrm{m}$, dan pada lapisan ke tiga di kedalaman 0,9 - 1,2 meter memiliki nilai resistivitas pada

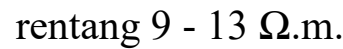

Berdasarkan pemodelan lapisan tanah didapatkan hasil yang menarik yaitu lihat pada Gambar 10 di lapisan ke tiga mendapatkan nilai 11,99 $\Omega . m$ di kedalaman 3,4-4,1 meter sedangkan pada Gambar 11 di lapisan ke dua mendapat nilai 11,19 $\Omega . m$ di kedalaman 2,1 - 3,1 meter, ada 2 kemungkinan hal tersebut terjadi pertama karena ukuran panjang elektroda yang

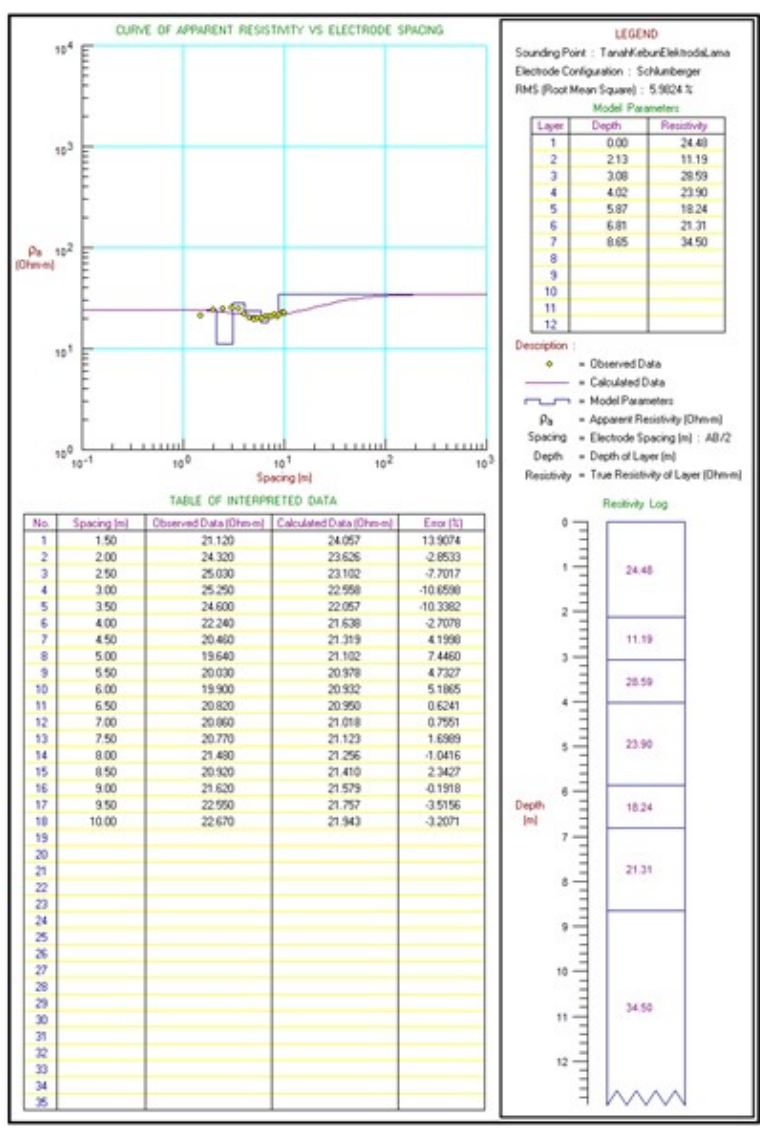

Gambar 11. Hasil Software Progress pada tanah kebun dengan elektroda lama

berbeda atau karena faktor tanah kebun yang cenderung gembur sehingga setelah penancapan pertama membuat tanah menjadi lebih gembur atau berongga sehingga mempengaruhi perbedaan nilai resistivitas pada lapisan tersebut.

Meski dari tiap lapisan tersebut memiliki nilai resistivitas yang bervariatif akan tetapi nilainya masih di bawah dari

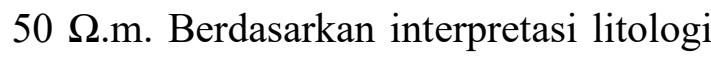
batuan terhadap hasil pemodelan pada Gambar 10 dan 11 bahwa lapisan tanah kebun tersebut masih berupa tanah lempung.

Mengacu pada RMS (Root Mean Square) atau error data yang 
diperbolehkan yaitu di bawah 10\% maka kedua profil data yang diperoleh sudah sangat bagus di mana untuk profil data dengan elektroda baru $5,65 \%$ dan profil data dengan elektroda lama 5,98\% [15].

\section{Simpulan}

Rekontruksi set alat praktikum geolistrik telah berhasil dilakukan dengan baik, elektroda baru yang telah dibuat secara desain memiliki tingkat efektif dan efisien yang disimpulkan dari hasil eksperimen yang telah dilakukan dengan memberikan kemudahan dalam penggunaan, tingkat K3 yang lebih baik, kecepatan pengambilan data dan lebih ringan dalam mobilisasi set alat dari sebelumnya. Dari segi fungsi elektroda baru ini memiliki fungsi yang sama karena menghasilkan pengukuran dengan error data di bawah $10 \%$.

\section{Ucapan Terima Kasih}

Penulis mengucapkan terima kasih kepada Rektor Universitas Pendidikan Indonesia yang telah memberikan Hibah Dana Penelitian Tahun Anggaran 2020, dengan Surat Keputusan Rektor Nomor: 1079/ UN40/PM/2020.

\section{Referensi}

1. Feranie, S., Iryanti, M., Utari, S., \& Ardi, N. D. (2008). Zona Migrasi Pencemaran Air di Sekitar TPA Babakan Ciparay Kabupaten Bandung dengan Menggunakan Metode Geolistrik Tahanan Jenis. Jurnal Hasil Penelitian.
2. Ardi, N. D., \& Iryanti, M. (2015, September). Resistivity mapping and geochemical data for groundwater contamination at Sarimukti municipal landfill, West Bandung. In AIP Conference Proceedings (Vol. 1677, No. 1, p. 060019). AIP Publishing LLC. 3. Ardi, N. D., \& Iryanti, M. (2016, February). Sliding zone identification of landslide area using resistivity method in Cijambe, Subang West Java. In AIP Conference Proceedings (Vol. 1708, No. 1, p. 070001). AIP Publishing LLC. 4. Ardi, N. D., Iryanti, M., Asmoro, C. P., Nurhayati, N., \& Agustine, E. (2018). Mapping landslide potential area using fault fracture density analysis on unmanned aerial vehicle (UAV) image. In IOP Conference Series: Earth and Environmental Science (Vol. 145, No. 1, pp. 1755-1315).

5. Ardi, N. D., Iryanti, M., Asmoro, C. P., Yusuf, A., Sundana, A. N. A., Safura, H. Y., ... \& Afrianti, R. (2018). Geoelectric imaging for saline water intrusion in Geopark zone of Ciletuh Bay, Indonesia. JPhCS, 1013(1), 012185.

6. Ardi, N. D., Iryanti, M., Agustine, E., Asmoro, C. P., Yusuf, A., Sundana, A. N. A., ... \& Afrianti, R. (2019, November). Monitoring of rainfall infiltration to under surface using DC resistivity method. In Journal of Physics: Conference Series (Vol. 1280, No. 2, p. 022063). IOP Publishing. 
7. Vebrianto, S. (2016). Eksplorasi Metode Geolistrik. Universitas Brawijaya Press. (2018). Modul Praktikum Geolistrik dan Elektromagnetik.

Universitas Tanjungpura, Pontianak.

8. Islami, N. PENGEMBANGAN PERALATAN PRAKTIKUM PADA MATAKULIAH FISIKA KEBUMIAN LANJUT. Jurnal Pendidikan, 9(2), 146154.

9. Sehah, S., \& Aziz, A. N. (2016). Pendugaan Kedalaman Air Tanah Menggunakan Metode Geolistrik Konfigurasi Schlumberger di Desa Bojongsari, Kecamatan Alian, Kabupaten Kebumen. Jurnal Neutrino: Jurnal Fisika dan Aplikasinya, 8(2. APRIL), 41-49.

10.Zubaidah, T., \& Kanata, B. (2008). Pemodelan fisika aplikasi metode geolistrik konfigurasi schlumberger untuk investigasi keberadaan air tanah. J Teknik Elektro, 7(1), 20-24.

11. Rubiantoro, P. (2016). PEMANFAATAN METODE GEOLISTRIK RESISTIVITAS KONFIGURASI SCHLUMBERGER DALAM PENDUGAAN LAPISAN AKUIFER UNTUK POTENSI AIRTANAH DI DESA CEMARA KECAMATAN SUBOH KABUPATEN SITUBONDO. Integrated Lab
12. Septyanto, B., Nafian, M., \& Dwiningsih, N. I. (2018). Identifikasi Lapisan Batuan Di Daerah Bojongsari, Depok Menggunakan Metode Geolistrik Resistivitas. Al-Fiziya: Journal of Materials Science, Geophysics, Instrumentation and Theoretical Physics, 1(2), 7-14.

13. Sohibun, S. (2019). Aplikasi Metode Geolistrik Konfigurasi Schlumberger untuk Mengidentifikasi Lapisan Air Tanah di Desa Ulak Patian Rokan Hulu Riau. Jurnal Fisika Flux: Jurnal Ilmiah Fisika FMIPA Universitas Lambung Mangkurat, 16(1), 54-60.

14. Iswahyudi, A., Prabawa, S. E., Warnana, D. D., \& Nur, J. P. G. (2017). Pengukuran Geolistrik Tahanan Jenis untuk Menentukan Letak Akuifer Air Bawah Tanah (Studi Kasus: Kecamatan Airmadidi, Kabupaten Minahasa Utara). In Prosiding Seminar Nasional Aplikasi Teknologi Prasarana Wilayah $X(A T P W)$, Surabaya (Vol. 5).

Journal, 4(1). 